\title{
How Organizational Unfairness Impedes Service Employees Needs Fulfillment? The Case of Islamic Banking Industry in Pakistan
}

\author{
Muhammad Farhan Hamid ${ }^{1}$, Sohail Kamran ${ }^{2 *}$, Qazi Waqas Ahmed ${ }^{3}$ \\ ${ }^{1}$ Department of English, Air University, Islamabad, Pakistan \\ ${ }^{2}$ Department of Business Administration, Fatima Jinnah Women University Rawalpindi, Pakistan \\ ${ }^{3}$ Department of Education, University of Jyvaskyla, Jyvaskyla, Finland
}

\section{Keywords}

Non-Managerial Employees

Low-Paid Staff

Islamic Banking Industry

Received: 07 April 2021

Accepted: 26 April 2021

\begin{abstract}
.
Purpose: The purpose of this study was to explore how organizational unfairness impedes fulfilment of various needs of non-managerial employees at Islamic banks.
\end{abstract}

Methodology: The data were gathered through semi-structured interviews from sixteen non-managerial employees of different fully Islamic bank branches located in Rawalpindi and Islamabad, Pakistan.

Findings: The study findings indicate that issues in the distributive, procedural and interactional justice elements of Islamic banks impedes fulfilment of basic, social, security, self-esteem, and self-actualization needs of non-managerial service employees of Islamic banks and adversely affects their wellbeing.

Significance: This research contributes to the literature on organizational fairness by unpacking the ways in which issues in the organizational justice elements impeded non-managerial service employees' life needs fulfilment. This study investigates the above-mentioned issue from the Islamic banks non-managerial employees' perspective, which was not empirically investigated earlier.

Limitations: The qualitative research findings might lack external validity or generalizability. In the future, a study could investigate this topic through survey research. Second, this research merely investigated how organizational unfairness impedes employees' life needs. In future, a study could explore the strategies employed by the employees encountering organizational unfairness for resolving the issues relating to stress and other socio-economic aspects.

Practical and Social Implications: This study findings provided an avenue to offer a number of practical implications to enhance fairness for non-managerial service employees in Islamic banks.

KAUJIE Classification: J3, J8

JEL Classification: G43, M73

(C) 2021 JIBM. All rights reserved.

\footnotetext{
${ }^{*}$ Corresponding author: Sohail Kamran

†Email: sohkam@hotmail.com; ORCID: https://orcid.org/0000-0002-8263-0908
} 


\section{INTRODUCTION}

Organizational justice is about the fair treatment of employees in all aspects of their work, which is depicted in distribution of resources, workplace procedures and interactions. Organizational justice enhances employees' productivity and wellbeing. The organizational unfairness, on the other hand, impedes organizational, workers and their families' wellbeing in different ways. Much of the employees' work stress stems from poor organizational policies and unfairness in distributions of resources, procedures, and interactions (Ceylan \& Seyfettin, 2011; Cropanzano et al., 2005; Okechukwu et al., 2014). Organizational fairness can produce immense benefits for both the organizations and their employees, such as increased customer satisfaction, commitment and enhanced job satisfaction and performance (Cropanzana et al., 2007), but a lack of organizational fairness affects employees' attitudes and behaviors, including their work satisfaction, absenteeism, workplace aggression, job stress, and organizational trust and also causes workplace alienation (Ceylan \& Seyfettin, 2011).

The vulnerable employees' e.g. low-paid workers could encounter organizational unfairness in different ways (Gardiner \& Millar, 2006). They could encounter distributive, procedural and interpersonal unfairness. Unfairness at the workplace could arouse feelings of powerlessness and societal isolation (Ceylan \& Seyfettin, 2011). Further, low-paid workers are at risk of poverty due to the uneven distribution of resources (Gardiner \& Millar, 2006). Employees work to fulfill their various needs, as explained by Maslow's Need Hierarchy Theory (1943). However, those encountering unfairness at the workplace may find it difficult to fulfill their basic, safety, social, self-esteem or self-actualization needs (Ceylan \& Seyfettin, 2011; Cropanzano et al., 2005; Maslow, 1943). The low-wage workers have to face great impediments in seeking fairness at the workplace (Kristen et al., 2015).

Organizational unfairness has a potential to adversely affect employees' personal and family wellbeing (Okechukwu et al., 2014). Low-wage workers might experience unfairness of different sorts at the workplace (Kristen et al., 2015). They are paid lower salaries which make it difficult for them to fulfill their basic financial needs which is against the fundamental human rights (Ayub, 2019). Similarly, they might also encounter different distributive, procedural and interactional unfairness, which potentially impedes their wellbeing in many ways. For example, it could impede the non-managerial service employees to fulfill their various needs as explained in the hierarchy of needs by Maslow (1943). The matter could be of even more concern if Islamic institutions like Islamic banks and other financial institutions, or corporate entities claiming to be applying Islamic principles in their business operations and workplace commit organizational injustice with their employees (Ayub, 2019). However, this issue remains unaddressed by previous researchers that show how unfairness in organizations distribution of resources, procedures and interactions impede non-managerial service employees to fulfill their various life needs. Therefore, the main aim of this research is to unpack how perceived or experienced unfairness among the non-managerial Islamic banking employees impedes fulfilment of their various life needs.

We choose Islamic banking non-managerial employees' context in this research owing to the reason that Islamic discipline as a whole and Islamic economics and finance, specifically, 
stand for justice and fair treatment with all stakeholders, including the employees. Prophet Muhammad (PBUH) said "Your employees are your brothers upon whom Allah has given you authority, so if a Muslim has another person under his control, he/she should feed them with the like of what one eats and clothe them with the like of what one wears and you should not overburden them with what they cannot bear and if you do so, help them in their jobs." [Șahịh al Bukhari, Kitab al Iman, Hadīth No. 30]. Although, Justice Theory has been extensively used to understand a variety of organizational fairness related issues (Cropanzano et al., 2007; Greenberg, 2010), but according to best of our knowledge, how organizational unfairness source impediments to non-managerial services employees in satisfying their life needs remains an unaddressed area. To explore this issue, we utilize both Justice Theory and Maslow Need Hierarchy Theory. Likewise, Islam teaches us justice in personal, social, and economic spheres. However, a few seminal researchers in the Islamic banking field have raised issues of unfairness with the Islamic banking lower-ranked employees in Pakistan, which is a serious issue. Those issues include low pays, longer working hours, lack of job security and other forms of exploitation (e.g. Ayub, 2019) for the sake of profit maximization (Syed \& Ali, 2010), but this issue has not been explored through empirical studies and from the perspective of Islamic banks' non-managerial employees. Therefore, it is worth examining explicitly how issues in the organizational justice elements of Islamic banks impede their non-managerial employee's ability to satisfy different needs, such as basic, social, security, self-esteem, and self-actualization needs (Maslow,1943).

\section{LITERATURE REVIEW}

Qur'ān and Sunnah urge the employers and senior staff to deal with their subordinates in a just manner. For example, Islam requires employers to pay their employees reasonable pay so that they could satisfy their life needs, and likewise, employers must not over-burden their employees (Syed \& Ali, 2010). Islamic banks position themselves on the notion of fair treatment of employees and other stakeholders (Ayub, 2019).

Islamic financial services providers ought to support social objectives and promote Islamic values towards their staff and other stakeholders (Duski, 2008). In light of the Islamic teachings the employees of Islamic banks must be treated fairly by their respective employers (Ayub, 2019). However, Islamic banks' non-managerial employees could encounter problems in their lives owing to incongruity between the claims of Islamic banks and their actual employees management practices. There is a higher imbalance between the salaries paid to the higher and the lower-level employees. Ayub (2019) maintains that Islamic bank employees encounter issues, such as work life balance, lower salaries which impedes them to comply with their basic needs and a lack of job security, among others (Ayub, 2019).

These issues in the working lives of non-managerial employees indicate unfair policies of Islamic banks towards their lower-level staff, which could compromise the non-managerial service staff's wellbeing and hamper them to comply with their different life needs (Ayub, 2019) . We discuss Organizational Justice Theory and Maslow Need Hierarchy Theory in the section below, which help us to comprehend how issues in the distributive, procedural 
and interactional justice elements of an organization could impede their employees to satisfy their life needs.

\section{Organizational Justice Theory}

The theory of organizational justice was introduced by Greenberg (1987). It has been widely used to unpack fairness in various business settings. It refers to how employees judge behaviour of an organization with regards to fairness. So fairness within organization refers to how actions and decisions of an organizations are perceived by employees on moral grounds. Morally right decisions are considered fair whereas, unethical decisions and actions of an organization are considered unfair (Tabibnia et al., 2008). There are three aspects of organizational fairness or justice which are distributive, procedural and interactional justice and these are generally evaluated to comprehend organizational fairness in various business settings (Seiders \& Berry, 1998).

The distributive fairness in an Islamic moral economy targets to obtain certain goals which include, satisfaction of basic human needs, establishing socioeconomic fairness and economic empowerment (Mulyany \& Furqani, 2019). Distributive Justice refers to the fairness of decisions and outcomes in distribution of resources (Adams, 1965). So it is just distribution of benefits and costs to the parties concerned (Laczniak, 1999). Distributive justice has three common aspects of equity, equality, and need fulfilment (Deutsch, 1975). Equity is related to the opportunity for obtaining better economic outcomes for all e.g. employees in the higher ranks are paid higher salaries based on their contributions. Equality means dividing resources equally to everyone within the organization, which is also considered a good tool to preserve pleasant social relations. Lastly, need-based allocation of resources is usually adopted when the goal is to enhance their employees' wellbeing (Deutsch, 1975). We can understand from the distributive justice element of justice theory that the non-managerial employees of banks must be paid such minimum wages that their common / basic needs of healthy food, and safe living are fulfilled. The virtues of benevolence, truthfulness, and justice, have been identified as the prime values that strengthen the social bonds in a society [Qur'ān 2: 177; $2: 195 ; 2: 261]$. While the younger members in the society and the junior/non-managerial employees in any organizations have been advised to pay respect to the senior and the higher cadre personnel, the seniors and the managers are advised to take care of socio-economic needs of the junior, and respect their human dignity. The Shari ${ }^{-}$ah tenets repeatedly exhort the employers/seniors to treat the servants and subordinates well. It is a natural law that some are rich and master, while the others are poor and servants "so that they may make use of one another for service" (43:32). This notion of justice is socio-economic in nature that also captures class differences and inequalities. Islam thus requires the employers to give appropriate compensation to the employees for the work done, sufficient to satisfy their basic everyday needs (Syed \& Ali, 2010).

Procedural fairness is regarding the individuals' perceptions of fairness in company's procedures (Tax et al., 1998). It is regarding the fairness in the processes which leads to results or outcomes (Nance \& White, 2009). The perception of procedural fairness can be improved, when employees have a voice in the organizational processes and the organizational pro- 
cesses are accurate, free from discrimination and bias, consistent, and morally justified. Only then the procedural fairness is perceived to be improved (Leventhal et al., 1980). Prophet Muhammad (PBUH) commanded his Ummah with integrity, justice, honour, equality, peace, and respect to humanity (Qadri et al., 2016). During the last sermon, Prophet Muhammad (PBUH) also stressed on equality of mankind. This also implies that every employee must be treated with similar procedures and there should not be any discrimination at least in organizations, such as Islamic banks which claim to operate their business according to the Islamic principles. Prophet Muhammad (PBUH) always treated his companions with great respect. His interactions with others were exemplary as he treated everyone with respect and kindness. This portrays that interactional justice is an important element of Islamic teachings. Interactional justice refers to the nature of treatment that employees receive from their organization (e.g. managers, supervisors) while working or dealing with them. It has two facets: interpersonal justice, and information justice. Interpersonal justice means how individuals are treated by their colleagues and superiors. The example of interpersonal fairness in business setting is to deal others with politeness and respect. Informational fairness refers to the provision of truthful, timely and adequate information to the concerned party (Seiders \& Berry, 1998). Organizational justice affects employee's wellbeing and could either facilitate or impede them to satisfy their life needs. Therefore, in the subsequent section, the Maslow need hierarchy theory is being explained which helps us to understand an individual's life needs.

\section{Maslow's Need Theory}

Abraham Maslow proposed one of the most famous theories of human motivation (Drummond, 2000). He suggested that for every individual there is a hierarchy of five needs. When one need is significantly fulfilled, the subsequent need arises (Bunchanan \& Huczynski, 1997). The five needs as elucidated within the Maslow's need theory are (a) Physiological needs, which include one's basic needs such as food, water and shelter etc. (b) Safety needs, such as protection from physical and emotional detriment (c) Social needs, such as affection and belongingness (d) Esteem needs include factors like, self-respect, autonomy, recognition and status and (e) Self-actualization needs comprise growth, achieving one's completest potential and self-fulfillment (Robbins, 1996). Maslow's theory (1943) has been extensively recognized, adapted to various business settings and criticized. The key criticism of this approach was the static explanation of events. Individuals by their very different nature and differing circumstances give a priority to different needs at different times and in different circumstances. This advocates that individuals are not, as Maslow explicates, but they are exclusive of each other and are changeable over time. Their needs could therefore be totally fulfilled on one time and remain unfulfilled on other times (Bent et al., 1999). Despite such limitations in Maslow's theory, issues of human needs have not been fully dropped in management research (Bent et al., 1999). 


\section{METHODOLOGY}

Qualitative interviews are considered a suitable method for exploring individuals opinions and experiences regarding different issues (Fox, 2009). This paper's aim is to investigate how the unfairness among the non-managerial service employees of Islamic banks impedes fulfilment of their various life needs. We conducted 16 semi-structured in-depth interviews with the bank's non-managerial service employees having experience of working in diverse entry-level roles. By non-managerial employees, we mean employees working in entrylevel positions who are not performing any management-related duties. Their working titles included Cashier, Business Development Officer, Customer Service Officer, Personal banking officer, and Customer Relationship Officers, etc. The study participants included 3 females and 13 males, their age ranged between 24 to 37 years and they had 01 year to 07 years of work experience in different non-managerial roles in the banking sector. Their per month salaries ranged in the bracket of 23000 to 37000 Pak Rupees (around 145-230 US $\$$ ). Nine participants were married, and seven were unmarried. The participants had various qualifications. One participant had completed a B.Com, four had a BBA, seven obtained an MBA, and four held an MS business administration degree. Table 1 shows the participants' profiles.

TABLE 1

Study Participants Profiles

\begin{tabular}{lllllll}
\hline \hline Sr. \# & Alias & Gender & Age & Qualification & Experience & Marital Status \\
\hline 1 & P-1 & Male & 32 & MBA & 03 Years & Single \\
2 & P-2 & Male & 34 & MBA & 03 Years & Married \\
3 & P-3 & Male & 36 & MS (Business) & 07 Years & Married \\
4 & P-4 & Female & 24 & BBA & 01 Year & Single \\
5 & P-5 & Male & 28 & BBA & 03 Years & Single \\
6 & P-6 & Male & 33 & MS (Business) & 05 Years & Married \\
7 & P-7 & Male & 35 & MBA & 05 Years & Married \\
8 & P-8 & Female & 26 & BBA & 03 Years & Married \\
9 & P-9 & Male & 36 & BBA & 07 Years & Married \\
10 & P-10 & Male & 37 & MS (Business) & 06 Years & Married \\
11 & P-11 & Male & 32 & MBA & 02 Years & Single \\
12 & P-12 & Male & 32 & MS (Business) & 03 Years & Married \\
13 & P-13 & Male & 29 & MBA & 02 Years & Single \\
14 & P-14 & Female & 25 & MBA & 02 Years & Single \\
15 & P-15 & Male & 28 & MBA & 01 Year & Single \\
16 & P-16 & Male & 34 & B.Com & 03 Years & Married \\
\hline \hline
\end{tabular}

All the interviews were completed in Urdu, the national language of Pakistan, but selected interview excerpts were translated into English language to report data in this research paper. The basic criteria to select participants was that they are employees of full service Islamic 
banks in Pakistan and are working in non-managerial roles. We used a snowball sampling technique to engage the study participants in this study. Initially, we engaged three participants who we believed were good fit to our research participants' requirement criteria. After completing their interviews, we requested them to refer more study participants who they think are the most suitable to participate in our study. So, all three participants, initially interviewed, helped us to recruit further study participants (Parker et al., 2019). Before starting each interview, the participants were explained the objectives of the research. All participants volunteered to participate in this research. We ensured all the interviewees about the confidentiality of their personal and organizational identity, and we used aliases to hide their identities while reporting this study findings.

We prepared an interview guideline to conduct this study which entailed different demographic questions. The participants were asked to express their views regarding their perceived unfairness in pay packages, procedures, and interactions in their respective bank branches. In addition, they were also asked how their perceived or experienced unfairness at banks impeded fulfilling their various life needs as proposed by Maslow (1943). We keep the wording and order of our questions very flexible, and this facilitated us to obtain detailed answers to our questions. We used Braun and Clarke (2006) thematic analysis approach to qualitative data analysis for analyzing the interview data. First, we transcribed the data and read that over and over again which improved our familiarity with the dataset. Second, we generated initial codes within the entire dataset. Third, we generated initial themes based on the coded dataset. Fourth, the initially named themes were reviewed to make sure that the participants answered the research question of this study and finally, we defined and named each theme in a way that those have relevance to the research question. We provided a number of quotes or verbatim of interviewees to support an explanation of the data and to support our argumentation.

\section{STUDY FINDINGS}

The analysis of interview data reveals that the non-managerial service employees of Islamic banks perceive their banks' policies, procedures, and allocation of resources impede fulfilment of their various needs. The factors impeding the banking employees' life needs were linked to the justice components of banks i.e. distributive, procedural and interactional justice. We analyzed how the study participants life needs were impeded by banks policies, procedures and allocation of resources by utilizing Maslow (1943) need hierarchy theory and justice theory.

\section{Physiological Needs}

The participants commonly reported that they find it difficult to fulfill their basic life needs with the salaries they get from their respective employers. They face distributive injustice element as the banks allocate lower salaries for them. Their salaries ranged from 23000 to 37000 Pak Rupees which made it difficult for them to fulfill their physiological needs such as food and shelter. Although this was a common concern of all the study participants, those who were married and those who were renting an accommodation in the city of Rawalpindi 
or Islamabad encountered this problem more severely than others. One of the participants explains this problem in the following manner:

I am renting a very small house in Rawalpindi which costs me 13000 Rs. and my monthly salary is around 30000 Rs. My bank [employer] does not pay any separate house rent to me. After paying for utility bills, food, dressing, and traveling, I have nothing left in my pocket. This thing worries me that I can't send anything to my parents and what will happen when I will get marry? [P-1, Male, aged 32].

Many study participants were the local residents of Rawalpindi or Islamabad, and they were living with their parents. However, those who were married commonly reported that because they have a little salary, which does not commensurate with their qualifications. They think that banks pay them lower salaries because banks know that there is too much unemployment, and it is easier for them to hire a person on lower wages. Nevertheless, lower salaries impede the fulfillment of basic needs. Some married participants were also engaged in small business after their banks working hours and on weekends. A number of married study participants reported to take an occasional loan from their siblings or friends to fulfill their life needs. They believe that banks should pay them reasonable salaries. Some operations staff reported working two or three extra hours each day, but no overtime was paid to them. They expressed a need for overtime for the extra hours they work on different days of the week. Similarly a few reported to get financial support from their parents in meeting their basic needs.

You know that different products prices are increasing day by day. Our salary is not increasing with the same speed. It is very difficult to afford things because of lower income. Sometimes, especially in the last days of the month I get some money from my father because we are left with nothing. Sometimes, when there is a marriage of some close relative or some other urgent need arises then we need money and then either I take a loan from my brother or friends. I think banks should pay us a reasonable pay so that we can fulfill our needs [P-3, Male, 36].

\section{Safety Needs}

The majority of study participants expressed their insecurities owing to an absence of pension policy, poor medical facilities, and lack of job security at Islamic banks. In addition, hiring of less qualified and experienced staff on upper ranks to the existing non-managerial staff also is a source of emotional harm to a number of study participants. These factors were linked to both distributive and procedural justice elements of banks and impeded security needs of our study participants.

The study participants could be divided into two broad categories i.e. sales and operations staff. Although both groups of employees expressed their insecurities, there were some differences in their concerns. Those who were working in the sales field were generally working on contracts. They felt particularly insecure owing to the banks' policies as they had no job security and proper medical facilities were not included in their job contract, which caused them insecurity. One of the participants explains his insecurities in the following manner: 
If I am ill, I have to incur expenses from my own pocket...if I am unable to get sales targets for two or three consecutive months then I could be fired from the job. Sometimes I am worried but then what can I do? Reasonable jobs are not available easily (P-16, Male, 34).

The operations staff we interviewed such as cashiers were less worried about the continuity of their job contracts as their job contracts were not conditional to obtaining specific sales targets. They are also paid provident fund when they leave their job or retire from their job at the age of sixty which was a source of positive feelings and security. However, their insecurities were caused by an absence of pension policy and weak medical facilities provided to them. Some participants informed that they and / or their dependents can be reimbursed a maximum of two hundred thousand Rupees per year only in case of admission to hospital and surgery. However, expenses incurred on general checkup in hospitals in the event of minor illness are not covered by the medical policy. One of the participants who works in operations in one of the Islamic banks elucidated his concerns in the following manner:

\begin{abstract}
Alhamdulillah [Thanks God], I have a job in this bank but I think their medical policies towards the staff, I mean especially lower level staff like me are not very good. I think they [bank] should improve their medical package for low level staff and also pension should be given. I have two kids and I often think that I am the sole earner and what will happen to my family if something happens to me. there is no pension as in case of government jobs (P-10, 37, Male).
\end{abstract}

Similarly, the sales department study participants told that there is always an extra pressure on them to get the sales targets. A number of participants from the sales domain informed that although they mostly achieved their sales targets with hard work and by using their social contacts, this fear always came to their minds that if they were unable to obtain sales targets then they might be fired from the job. Moreover, the sales department participants expressed that their managers put extra pressure on them to achieve sales targets which are sometimes not possible or very difficult to achieve. This all sourced insecurity and mental harm to a number of study participants. A study participant explains his opinion in the following way:

Each month there is a pressure of getting sales targets. Mostly I get the sales targets. I do a lot of hard work to get my sales targets. Sometimes I ask my family members and friends to invest money in my branch but it is very difficult work... this fear often comes to my mind that my job contract is not permanent and if I am unable to get sales target I will be fired from the job ( $P-15$, Male, 28 years).

\title{
Social Needs
}

The study participants overall reported that their working environment is good and colleagues generally behave positively with each other. They are ready to help each other in times of need and the cooperation is generally reciprocal which aroused feelings of affection and belongingness among the employees, we interviewed. So, the study participants generally perceived that their colleagues and working environment help fulfilling their social needs at 
the workplace. However, they also identified a number of procedural and interactional unfairness at their workplace which hampered fulfillment of their social needs in different ways. The procedural unfairness was related to banks policies and culture. Whereas, perceived interactional unfairness was related to the study participants perceived discrimination against them by their bosses at workplace. A few participants told during the interviews that those in the high positions don't talk with them in a friendly manner and try to maintain a distance with them. A couple of selling staff told that their sales manager doesn't listen to them when setting sales targets. In addition, a participant told that he often observes interactional unfairness in a way that managers treat different non-managerial staff members in a different manner. Those who are near to the boss are treated well and their small mistakes are ignored and they are facilitated in different manners by the manager. However, those who are not near to the boss and are not favorites get differential treatment which arouses feelings of being ignored and less useful than others. This interactional unfairness impeded fulfillment of social needs of our participants at the workplace. The participants reported that this kind of discriminatory behavior made them feel that if they were not part of the organization. One of the study participants expressed his concerns in the following manner:

\section{I have been working here as a sales officer for the last two years and I noticed that different colleagues are treated differently by our manager. I mean boss sometimes do favoritism...means those who are near to boss will go and sit with him and boss will give those colleagues favours but some of us are not given those favours...he will listen to the suggestions of our those colleagues who are near to him...for example when I will give some suggestion about ways of obtaining sales targets he will not listen...Sometimes I feel that if I am not part of this team (P-13, Male, 29 Years).}

The participants reported that no formal induction and welcome party was arranged by the bank branch when they joined the branch. Similarly, a number of employees reported that formal lunch, dinner and formal events are not arranged by banks especially for the non-managerial employees. The participants feel that banks don't arrange such events for their employees because they want to save costs. However, they expressed a need for such events which could help them to socialize with other employees and increase their social network. Nevertheless, this impedes social needs fulfilment of employees. One of our study participants explains this as follow:

There are no events that are arranged for the employees to socialize... I think these events can help us to meet with new people and increase our professional contacts (P-7, Male, 35 Years).

A number of study participants working in the operational department complained about unpaid extra working hours. A couple of employees reported to work on public holidays for keeping ATMs functioning as cash could finish in ATM machines. To maintain availability of cash in ATMs they were supposed to look after ATMs on Eid days and on different other public holidays etc. However, the bank neither paid them for traveling nor for their overtime which caused them mental and social harm. They believe that their work life balance is 
harmed as they are supposed to be with their family on those days. In addition, both male and female staff working in operations banking areas raised their concern on overtime i.e. the hours they work after 5:00 PM. They believe that banks should give them overtime for work performed after 5:00 PM. The extra hours often created work life balance issues in the lives of our study participants but it was especially difficult for the female participants to work additional hours after their official working hours. One of the female participants who works in operations explains her feelings in the following manner.

Often we have to stay there at banks for 2 to 3 extra hours after the closing time...I have to complete my house chores as well after the job...Due to extra hours working my husband sometimes says me to leave the job, but I think at least I have got a job and earning something for myself and for my family ( $P-8$, Female, 26 Years).

\section{Esteem Needs}

Although a number of the study participants' accounts reveal that their esteem needs (i.e. self-respect and recognition) were somewhat fulfilled in their workplace, several participants also raised issues which signal that their esteem needs are not fulfilled at the workplace. The unfulfilled esteem needs of the study participants were linked to the procedural and interactional justice elements of Islamic banks. Our study participants' stories reveal that their esteem needs were not fulfilled owing to their perceived interactional unfairness. Their accounts tell that sometimes their unpleasant interactions with their managers' were the main cause of the aforementioned issues.

There were mixed answers about self-respect at the workplace. Majority of employees reported that their managers and colleagues care for their self-respect. However, a couple of participants working in the sales department reported that their managers were harsh to them and sometimes insulted and threatened to fire them from the job when they were unable to obtain their sales targets. This sourced them insult, feeling of disrespect and social harm. One participants explains this as follow:

I was unable to get my sales target in the last two months. My manager told me in front of two other colleagues that you are very lazy. If you are having this poor performance next month too, then you may be fired from the job...I was sad and felt insulted in front of my friends [colleagues] (P-13, 29 Years, Male).

One of the particular issue raised by the majority of our study participants was the lack of recognition of their work. Both categories of employees working in operations and sales departments highlighted this issue but in a different manner. The sales staff employees reported that meeting sales targets is considered a normal thing and good performance is not praised by their respective managers. Contrarily, operations departments expressed their grievance regarding the non-recognition of their hard work that they do in the shape of working unpaid extra hours spent after the normal working hours at the bank branch, and in the shape of occasional extra hours on public holidays (e.g. to deal with ATM issues). The following excerpts taken from two different interviews highlight the aforesaid issues. 
Everyone likes to be praised for their hard work and good performance. When sales targets are not met then sales managers are sometimes harsh but when we get the sales targets they don't even praise our efforts ( $(P-13,29$ Years, Male).

It is normal to work sometime after the closing time [5:30 PM] at the bank branch but neither are we paid for that overtime nor we are praised by our managers for the extra time worked in the branch...I think this is rather discouraging and demotivating factor for me (P-4, Female, 24 years).

\section{Self-Actualization Needs}

The study participants were unable to fulfill their self-actualization needs owing to perceived unfairness in their organizations promotion and hiring decisions on managerial positions. Likewise, they commonly reported that their full potential is not being utilized by their organization and they have a little expectation that they can fulfill their hopes and ambitions associated with their profession. The study participants' stories reveal that their self-actualization needs remain unfulfilled owing to the problems in banks' distributive and procedural justice components.

A number of employees expressed a strong need to grow in their professions, but there are barriers to their promotion within their respective organizations. They also perceive that they are not working according to their full potential. A number of study participants reported that they can use their academic qualifications in a better manner in managerial jobs at their respective banks, but lack of growth opportunities disappoints them. The participants perceive that politics, favoritism and employees grouping within their banks hinder them to grow within their respective organizations. A number of employees expressed their grievance regarding lack of promotion opportunities within their bank. They perceived that favoritism and violation of merit is common as banks often hire outsiders on higher posts and existing non-managerial employees are frequently ignored for promotions. The participants' stories indicate that hiring external candidates cause them demoralization and enhance their intentions to leave. In addition, this practice enhances jealousy and politics between the employees which could decrease productivity. The following interview excerpt explains this issue:

I have an MS business degree and it's my right to be promoted. I am very confident that I can work on some managerial role easily... due to my qualification and experience...I have worked in [XYZ] bank for many years but they are not willing to promote me to next position... One of superior who came from other bank knows less than me and he is lesser qualified than me but he might have strong reference in the bank... this hurts when your right is given to someone else who does not even deserve that...I feel demotivated but then job is a job, but I am searching for a better position in other banks (P-3-36 Years, Male).

The study participants commonly perceived and reported that their hopes, desires and ambitions remain unfulfilled owing to the banks allocation of resources and procedures which are linked to banks distributive and procedural justice elements, respectively. A few 
participants hoped that they would be promoted to next rank after their good performance, experience and improvement in qualifications but their expectations remained unfulfilled. Likewise, some participants were of the view that they are never included in the branch level decisions which is a demotivating factor. They reported that non-managerial employees are generally not asked for their input in decisions but they perceived that their participation could certainly give an opportunity to them to enhance their learning and utilize their creative and decision making talents. A number of study participants expected that they might be able to improve their academic qualifications by taking study loans from banks and their respective banks might facilitate their evening time or week-end university education. However, a couple of participants' disappointment and resentment was obvious in their stories because their respective banks did not offer them any study loan or facilitation to complete university degrees in evening time. One of the participants explained this in the following manner:

I wanted to start an MS [Masters of Science] degree from ... university in the evening time. Their fee was not affordable for me and I thought my bank would give me a study loan. I asked about a study loan with my branch manager who told me that there was no policy of study loan...There was no other kind of help from the bank to complete an MS... Then I decided not to do MS due to no facilitation from bank... I wanted to do MS because I wanted to grow in my professional life (P-3-36 Years, Male).

We concludes that non-managerial service employees who were the study participants of this research perceived or actually experienced distributive, procedural or interactional unfairness which impeded fulfilment of their different life needs and adversely affected their wellbeing.

\section{DISCUSSION}

This study explored how organizational unfairness impedes non-managerial service employees to fulfill their needs. We utilize Justice Theory and Maslow's need hierarchy theory to answer our research question. The study findings reveal several problems in distributive, procedural and interactional justice aspects of Islamic banks, which hinder the non-managerial service employees to satisfy their different needs. First, the non-managerial employees struggle to satisfy their different physiological needs of themselves and their immediate family members owing to lower salaries paid to them, which is directly linked to the Islamic banks distributive justice aspect. Banks pay them very low salaries which impede fulfilment of their physiological needs.

Second, the study results indicate that non-managerial employees have a sense of insecurity, which stems from an absence of pension policy for their employees, poor medical facilities, and lack of job security. Job insecurity causes 'bread and butter' issue for the employees leading ultimately to class-rift and social unrest in societies (Ayub, 2019). These issues hindering non-managerial service staff impeding their security needs are associated with both distributive and procedural elements of banks. To enhance fairness, banks should formulate policies for enhancing job security of their non-managerial staff and improve 
medical facilities for them. Third, study participants identified a number of issues which hamper fulfilling their social needs which were associated with procedural and interactional unfairness of banks. The procedural unfairness was linked to the Islamic banks policies as there is an absence of different social events which hinders non-managerial employees to increase their professional network. The organizational justice also requires a balance in work-relief/convenience / leisure balance. For a coherent and peaceful organizational culture and society at large, there must also be work-family-leisure balance so that employees could fulfill their families and the society related responsibilities properly (Ayub, 2019). However, overtime and work on different public holidays damaged the work life balance of study participants and impeded their social needs which is a procedural justice element of banks. The interactional unfairness was related to the study participants perceived or experienced discrimination, favoritism and differential treatment of employees at workplace. Fourth, the participants' esteem needs remained unfulfilled owing to the interactions with their superiors that damaged their self-respect and a lack of recognition of work done also impeded fulfilment of esteem needs, which were linked to the Islamic banks procedural and interactions justice elements. Finally, the non-managerial employees at Islamic banks self-actualization remained unsatisfied owing to the issue in banks distributive and procedural justice aspects. The internal non-managerial employees generally perceive that it is difficult for them to be promoted in their organizations and things they hoped to achieve from their professional careers remain unachieved e.g. growth, personal development etc.

According to the vision and mission statements of various Islamic banks in Pakistan, the objective of Islamic banking is to facilitate implementing an equitable economic system, providing a strong foundation for establishing a fair and just society for mankind. It necessarily requires justice and fair treatment with own employees of the banks who add value and earn profits for the shareholders (Ayub, 2019). However, based on this study findings we concluded that non-managerial service employees' various needs are not fully satisfied which has various adverse consequences to their wellbeing. The basic cause of unsatisfied needs of non-managerial employees at their respective workplaces were perceived or experienced unfairness i.e. distributive, procedural and interactional. Therefore, we propose the following recommendations to satisfy non-managerial employees' needs and to enhance their employees' organizational fairness perception and their wellbeing. This notion of justice is socio-economic in nature that also captures class differences and inequalities Islam thus requires the employers to give appropriate compensation to the employees for the work done, sufficient to satisfy their basic everyday needs (Syed \& Ali, 2010). However, various other researchers note that Islamic banks pay Rs. 20,000 to 30,000 (US\$120-180 per month) to the graduate and even postgraduate employees of banks, for long hours, just because they agree on that amount due to fewer employment opportunities and low potential of entrepreneurial development (Ayub, 2019). The regulator and the senior management of Islamic banking industry has to oversee and rethink the banks' salary structure. Profit maximization' has to be mediated by concerns for the welfare of the employees and the society at larger and should not be an overriding priority of banks (Syed \& Ali, 2010). So, firstly, to enhance distributive fairness, the Islamic banks should pay a reasonable salary to their non-managerial staff so 
that they could fulfill their basic life needs. Second, the non-managerial employees feel insecure owing to a lack of job security and medical facility among others. This insecurity was severe among non-managerial sales employees who were working on contract basis. The Islamic banks should give similar contracts to both sales and operational staff and should also enhance their medical packages for enhancing fairness in the minds of non-managerial service employees. Third, Islamic banks should occasionally arrange social events to satisfy employees' social needs. In addition, unpaid overtime on regular days and especially on public holidays deteriorates work life balance of non-managerial employees and compromises fulfillment of their social needs. We suggest that overtime working hours should be paid and employees consent must be taken before involving them in overtime or extra work. This could enhance feelings of procedural and distributive fairness among non-managerial service employees. Likewise, Islamic banks should devise a policy against nepotism, favoritism and discrimination at workplace for those working in managerial positions which could enhance possibility of promotion of the non-managerial service employees. Fourth, fairness and proper balance are required about the business targets given to the employees keeping in view the nature of banking business and the need for ensuring Shari ${ }^{\top}$ ah compliance of business transactions both on deposits and the financing sides (Tahir, 2003). Those sales managers damaging the self-respect of their subordinates should be held accountable. The banks should encourage the non-managerial service employees to complain in case of any uncivilized behavior of their superiors. This could enhance non-managerial employees' feelings of procedural and interactional fairness in their respective banks. Finally, Islamic banks should develop a career path for the non-managerial employees and candidly inform the objective criteria of promotion to the next ranks.

\section{Conclusions}

Justice is central to Islamic teachings, and it affects people's wellbeing in any society. Organizational fairness is regarding the just treatment of employees in all aspects of their work, which is related to distribution of resources, workplace procedures and interactions. Fairness at the workplace enhances employees' productivity and wellbeing, while organizational unfairness impedes organizational, workers and their families' wellbeing in different ways. Only a handful of researchers raised the issue of unfair treatment of non-managerial employees in Islamic banks of Pakistan in their conceptual papers (Ayub, 2019). Nevertheless, there was no prior study investigating how Islamic banks treat their non-managerial employees in Pakistan. This study investigated the issue from the non-managerial employees' perspective.

This research's aim was to investigate how perceived, or actual organizational unfairness impedes Islamic banks' non-managerial employees to satisfy their life needs. This research finds that Islamic banks' non-managerial employees commonly encounter distributive, procedural and interactional unfairness which hampers them to satisfy their physiological or basic needs, basic social, security, self-esteem and self-actualization needs. Islam stresses fairness in all spheres of life i.e. personal, social, and economic. Islamic banks operate in the economic sphere by claiming to apply Islamic principles of justice, but this research findings reveal otherwise. The Islamic banks in Pakistan don't really care about satisfy- 
ing their non-managerial employees' different life needs. The non-managerial employees consider their treatment by Islamic banks as unfair which was linked to the allocation of resources, procedural and interactional justice elements of the Islamic banks in Pakistan. This research provides a number of suggestions to Islamic banks for improving wellbeing of their non-managerial employees.

This research is qualitative in nature and tried to comprehend organizational unfairness from non-managerial employees' perspective. However, this research might lack external validity or generalizability. Therefore, a future study could investigate this topic through a questionnaire or survey research. Second, this research only investigated how organizational unfairness impedes employees' life needs' fulfilment. However, individuals might face stress when they are unable to fulfill their life needs. So a future study could explore the strategies employed by the employees encountering organizational unfairness for resolving the issues relating to stress and other socio-economic aspects.

\section{REFERENCES}

Adams. J. S. (1965). Inequity in social exchange. In: Berkowitz, L. (Ed.), Advances in experimental social psychology. New York, NY: Academic Press.

doi: https://doi.org/10.1016/S0065-2601(08)60108-2

Ayub, M. (2019). Islamic bankers to have the prior right to justice and fair treatment. Journal of Islamic Business and Management, 9(1), 1-13.

doi: https://doi.org/10.26501/jibm/2019.0901-001

Bent, R., Seaman, C. E. A., \& Ingram, A. (1999). Staff motivation in small food manufacturing enterprises. British Food Journal, 101(9), 654-667.

doi: https://doi.org/10.1108/00070709910288847

Braun, V., \& Clarke, V. (2006). Using thematic analysis in psychology. Qualitative Research in Psychology, 3(2), 77-101. doi: https://doi.org/10.1191/1478088706qp063oa

Bunchanan, D., \& Huczynski, A. (1997). Organization behaviour, an introductory text. New York, NY: Prentice Hall.

Ceylan, A., \& Seyfettin, S. (2011). Organizational injustice and work alienation. Ekonomika A Management, 2, 65-78.

Cropanzana, R., Bowen E. D., \& Gilliland W, S. (2007). The management of organizational justice. Academy of Management Perspectives, 21(4), 34-48. doi: https://doi.org/10.5465/amp.2007.27895338

Cropanzano, R., Goldman, M. B., \& Benson II, L. (2005). Organizational justice and work stress. In Handbook of work stress. Thousand Oaks, CA: Sage Publications.

Cropanzano, R., Bowen, D. E., \& Gilliland, S. W. (2007). The management of organizational justice. The Academy of Management Perspectives, 21(4), 34-48. doi: https://doi.org/10.5465/amp.2007.27895338

Deutsch, M. (1975). Equity, equality, and need: What determines which value will be used as the basis of distributive justice. Journal of Social Issues, 31(3), 137-149. doi: https://doi.org/10.1111/j.1540-4560.1975.tb01000.x 
Drummond, H, (2000). Introduction to organizational behaviour. New York, NY: Oxford University Press.

Duski, W., A. (2008). Understanding the objectives of Islamic banking: A survey of stakeholders' perspectives. International Journal of Islamic and Middle Eastern Finance and Management, 1(2), 132-148. doi: https://doi.org/10.1108/17538390810880982

Fox, N (2009). Using interviews in a research project. The Research Design Service for Yorkshire \& the Humber, National Institute for Health Research, UK.

Gardiner, K., \& Millar, J. (2006). How low-paid employees avoid poverty: An analysis by family type and household structure. Journal of Social Policy, 35(3), 351-369. doi: https://doi.org/10.1017/S0047279406009822

Greenberg, J. (1987). A taxonomy of organizational justice theories. Academy of Management Review, 12, 9-22. doi: https://doi.org/10.5465/amr.1987.4306437

Greenberg, J. (2010). Organizational injustice as an occupational health risk. The Academy of Management Annals, 4(1), 205-243.

doi: https://doi.org/10.5465/19416520.2010.481174

Kristen, E., Banuelos, B., \& Urban, D. (2015). Workplace violence and harassment of low-wage workers. Berkeley Journal of Employment and Labor Law, 36(1), 169-204.

Laczniak, G. R. (1999). Distributive justice, catholic social teaching and the moral responsibility of marketers. Journal of Public Policy E Marketing, 18(1), 125-129. doi: https://doi.org/10.1177/074391569901800114

Leventhal, J., Karuza, J., \& Fry, W. R. (1980). Beyond fairness: A theory of allocation preferences. In G. Mikula (Ed.), Justice and social interaction (pp. 167-218). New York, NY: Springer-Verlag.

Maslow, A. H. (1943). A theory of human motivation. Psychological Review, 50(4), 370-96. doi: https://doi.org/10.5465/19416520.2010.481174

Mulyany, R., \& Furqani, H. (2019). Sharing prosperity: Distributive justice framework in an Islamic moral economy. Madania: Jurnal Kajian Keislaman, 23(2), 117-126.

Nance, W., \& White, D. (2009). Service performance and procedural justice: The mediating roles of family life cycle and culture. Journal of Services Marketing, 23(3), 195-207. doi: https://doi.org/10.1108/08876040910955206

Okechukwu, C. A., Souza, K., Davis, K. D., \& De Castro, A. B. (2014). Discrimination, harassment, abuse, and bullying in the workplace: Contribution of workplace injustice to occupational health disparities. American Journal of Industrial Medicine, 57(5), 573-586. doi: https://doi.org/10.1002/ajim.22221

Parker, C., Scott, S., \& Geddes, A. (2019). Snowball sampling. In P. Atkinson, S. Delamont, A. Cernat, J. W. Sakshaug, \& R. A. Williams (Eds.), SAGE research methods foundations. New York, NY: Sage Publications.

Qadri, A. M., Qadri, S., \& Ahsan, L. (2016) The administration of Prophet Muhammad (PBUH) and its impact on the contemporary states. Journal of Philosophy, Culture and Religion, 17, 30-34.

Robbins, P. S. (1996). Organizational behavior (7th ed.). London, UK: Prentice Hall International Limited. 
Seiders, K., \& Berry, L. L. (1998). Service fairness: What it is and why it matters. The Academy of Management Executive, 12(2), 8-20.

doi: https://doi.org/10.5465/ame.1998.650513

Syed, J., \& Ali, A. J. (2010). Principles of employment relations in Islam: A normative view. Employee Relations, 32(5), 454-469.

doi: https://doi.org/10.1108/01425451011061630

Tabibnia, G., Satpute, A. B., \& Lieberman, M. D. (2008). The sunny side of fairness: Preference fairness activates reward circuitry (and disregarding unfairness activates self-control circuitry). Psychological Science, 19, 339-347. doi: https://doi.org/10.1111/j.1467-9280.2008.02091.x

Tahir, S. (2003). Islamic banking in Pakistan-Problems and prospects. Retrieved from: URL: https://www.sbp.org.pk/departments/ibd/Lecture_8_Related_Reading_1.pdf

Tax, S., Brown, S., \& Chandrashekaran, M. (1998). Customer evaluations of service complaint experiences: Implications for relationship marketing. Journal of Marketing, 62(2), 60-76. doi: https://doi.org/10.1177/002224299806200205 